\title{
Initial borehole results from the Amery Ice Shelf hot-water drilling project
}

\author{
Mike CRAVEN, ${ }^{1}$ Ian ALLISON, ${ }^{1}$ Russell BRAND, ${ }^{1}$ Alan ELCHEIKH, ${ }^{1}$ John HUNTER, ${ }^{2}$ \\ Mark HEMER, ${ }^{3}$ Shavawn DONOGHUE ${ }^{2}$ \\ ${ }^{1}$ Antarctic ACE-CRC and ${ }^{2}$ Australian Antarctic Division, Private Bag 80, Hobart, Tasmania 7001, Australia \\ E-mail:m.craven@utas.edu.au \\ ${ }^{3}$ Martin Ryan Marine Institute, National University of Ireland, Galway, Ireland
}

\begin{abstract}
The Amery Ice Shelf Ocean Research (AMISOR) project aims to examine and quantify processes involved in the interaction between the ice shelf, the interior grounded ice and the oceanic water masses that circulate beneath it. Two boreholes were melted through the shelf, within $100 \mathrm{~km}$ of the calving front, to access the ocean cavity. One (AM02) was at a site where it was believed that basal melt was occurring, and the other (AM01) was in a region with accreted marine ice. At both sites the summertime ocean structure revealed meltwater-modified boundary layers up to $100 \mathrm{~m}$ thick immediately beneath the shelf. Salinity and temperature data in the upper cavity at AM02 showed a strong seasonal cycle as a result of a combination of ice-shelf basal melt, and the intrusion of ocean water masses modified by sea-ice processes in Prydz Bay. At AM01, a $200 \mathrm{~m}$ thick layer of marine ice underlay the meteoric ice, and showed an increase in salinity and decrease in stable-isotope fractionation with depth. The lowest $100 \mathrm{~m}$ of marine ice was highly permeable, with a rectangular banded textural facies. Other preliminary results from this study are also reported.
\end{abstract}

\section{INTRODUCTION}

Antarctic ice shelves are important components of the climate system where basal melting and freezing processes can significantly modify large water masses circulating in the ocean cavities beneath them (Foldvik and Gammelsrød, 1988; Nicholls and others, 1991). Contrary to early evidence from small ice shelves like the Wordie (Vaughan, 1993), the recent collapse of larger ice-shelf sections (Larsen A; Prince Gustav Channel) in the Antarctic Peninsula has led to accelerated discharge of grounded ice, and is likely through glacio-eustasy to directly impact on global mean sea-level variations (Rott and others, 2002; De Angelis and Skvarca, 2003).

The Amery Ice Shelf (AIS) and the inland Lambert Glacier drainage basin, occupying a total area of $1550000 \mathrm{~km}^{2}$, incorporating $58000 \mathrm{~km}^{2}$ of floating ice, form the largest glacier-ice-shelf system in East Antarctica (Fricker and others, 2002a). A new delineation of the grounding zone for the AIS has been determined from hydrostatic equilibrium calculations using a satellite altimetric digital elevation model (DEM), radio-echo sounding measurements, satellite imagery and mass-balance considerations (Fricker and others, 2002b). This places the grounding line of the AIS as far south as $73.2^{\circ} \mathrm{S}$. The mass-flux estimates indicate that at least half the continental ice flowing into the AIS is lost through basal melt within the first $100 \mathrm{~km}$ of the ice becoming afloat. Some of this is later accreted back on to the base of the northwest sector of the ice shelf as marine ice (Fricker and others, 2001). Oceanographic observations of the modification to the salinity and temperature of water masses entering and exiting the ice-shelf cavity indicate a similar net mean annual melt loss (Wong and others, 1998).

Processes of interaction between ice shelves and the sea water in contact with them, as well as the sensitivity of these processes to changes in ocean temperature and circulation patterns near Antarctica, are important both to the Antarctic mass budget and to the modification of water-mass characteristics. The Amery Ice Shelf Ocean Research (AMISOR) project aims to: quantify the interaction between the ocean and the AIS; determine the implications of this interaction for the discharge of grounded ice and for watermass modification; and derive a long-term record (from sediment and ice cores) of the time variability of the interaction. It builds on previous glaciological investigations of the Amery Ice Shelf-Lambert Glacier drainage basin (Budd, 1966; Allison, 1979; Budd and others, 1982; Fricker and others, 2001, 2002a, b; Young and Hyland, 2002), and of the Prydz Bay oceanography (Smith and others, 1984; Wong and others, 1998) and sedimentary record (O'Brien and Harris, 1996; Domack and others, 1998).

AMISOR employs a multidisciplinary approach to the study of the region. The project includes components of hotwater drilling (HWD) through the AIS to access the underlying cavity; glaciological measurements of the iceshelf velocity, strain and thickness; oceanographic measurements in Prydz Bay; investigation of sub-ice-shelf sediments and sediment dynamics; remote sensing; and numerical modelling of ice-shelf-ocean interaction and ice-shelf dynamics. This paper describes initial results obtained from two HWD boreholes melted through the ice toward the front of the AIS, after an initial test season near the northeast edge of the shelf in 1999-2000 (Fig. 1).

\section{THE AMISOR HOT-WATER DRILL (HWD) SYSTEM}

A modular HWD system was designed and built in-house, with the capability of drilling a $250 \mathrm{~mm}$ or greater diameter borehole to $1000 \mathrm{~m}$ in cold ice. System component specifications were determined from the results of calculations of borehole freezing rates using formulations as described by Napoléoni and Clarke (1978), Taylor (1984), Iken and others, (1989) and Humphrey and Echelmeyer (1990). 


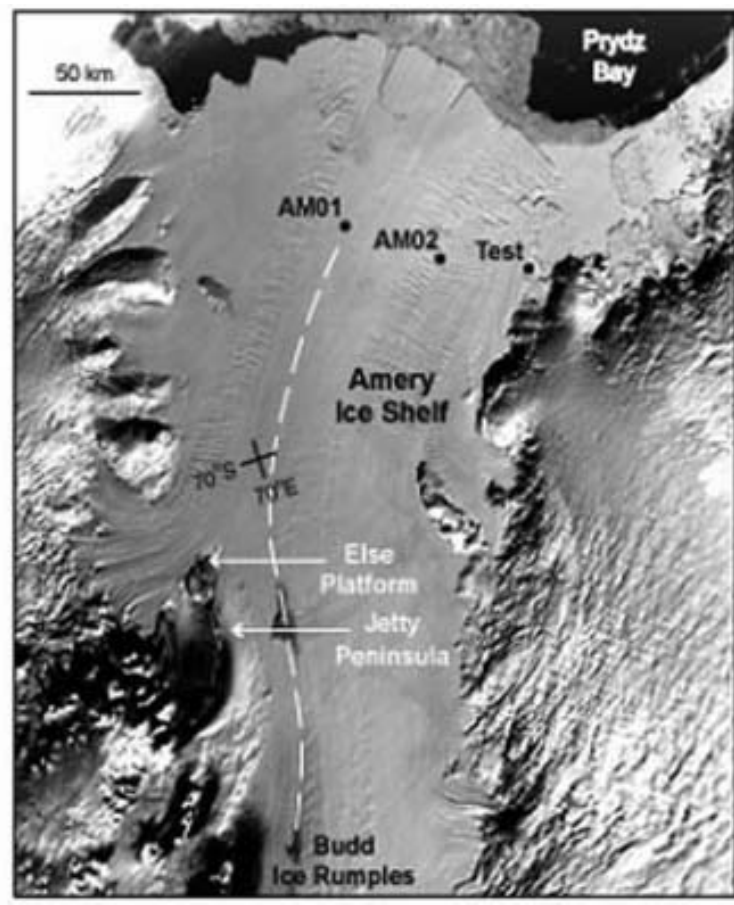

Fig. 1. Amery Ice Shelf location map indicating sites of AMISOR HWD operations (AM01 is at the same geographic location as an earlier 1968 ice-coring site). The dashed curve follows an approximate flowline from the Budd Ice Rumples (BIR) upstream of the AM01 drill site.

The AMISOR HWD (Fig. 2) is powered by a Hatz $12 \mathrm{kVA}$ three-phase diesel generator, with an identical Hatz bareshaft motor driving a CAT 1051 high-pressure surface pump for delivering water at rates up to $45 \mathrm{Lmin}^{-1}$. Up to six $80 \mathrm{~kW} \mathrm{~K}^{\prime}$ Archer Volcano industrial heaters are plumbed in parallel via inlet and outlet manifolds to heat the water to around $80^{\circ} \mathrm{C}$. The system uses 1 in $(50 \mathrm{~mm})$ internal diameter $580 \mathrm{~N}-16$-SL thermoplastic hose in $600 \mathrm{ft}$ lengths $(183 \mathrm{~m})$, to deliver hot water to a $90 \mathrm{~kg}$ stainless-steel drill stem via a motor-driven hose drum winch, and an electronically controlled capstan drive. A set of Spraying Systems nozzles, covering a range of outlet diameters, deliver either a solid stream or full cone spray to the borehole depending on whether drilling is underway in a water-filled ice cavity, or in the upper air-filled porous firn section of the hole. The HWD water supply comes from melted snow stored in a StructureFlex $12000 \mathrm{~L}$ portable water tank free-standing on insulated boards set out on the snow surface. A subsurface water recovery system is employed using a Grundfos SP5A-38 $4 \mathrm{~kW}$ submersible pump in an adjacent shallow hole, with hydraulic connection near sea-level depth with the main borehole. This method has been described and successfully employed elsewhere, such as on the Ross Ice Shelf (Browning and others, 1979; Koci, 1984), the Ronne Ice Shelf (Nicholls and others, 1991; Makinson, 1993), and ice streams in West Antarctica (Engelhardt and others, 1990).

\section{FIELD OPERATIONS}

\subsection{HWD borehole sites}

The borehole site selection for the AMISOR project was based on knowledge of the distribution of marine ice accreted to the base of the shelf (Fricker and others, 2001)

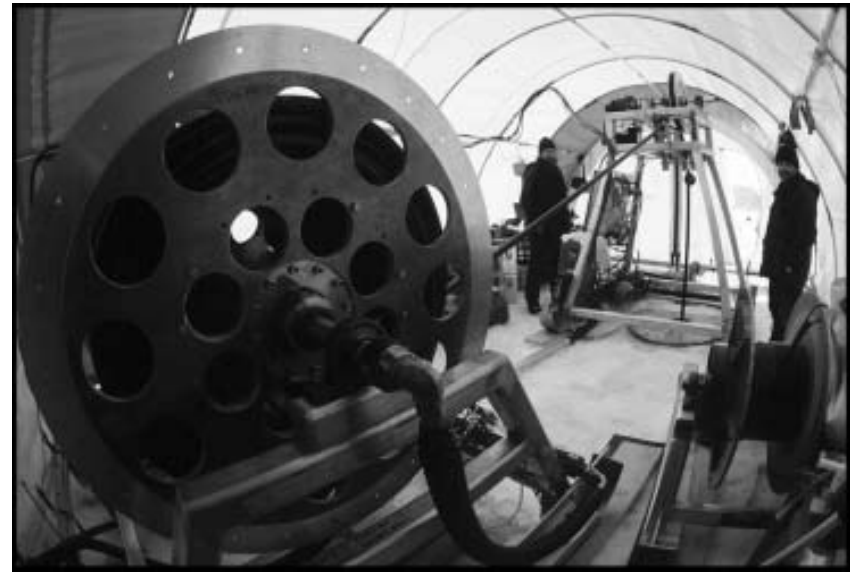

Fig. 2. Set-up of the AMISOR HWD drill tent with hose winch in left foreground and capstan stand over the borehole in right background.

and aligned with previous AIS glaciological survey grids (Budd and others, 1982). It was expected that a borehole array across the AIS, near the front, would sample regions of both melting and freezing basal conditions.

In the 2000/01 season a 300-350 mm diameter $373 \mathrm{~m}$ deep borehole was drilled at a northeastern site AM02 $\left(69^{\circ} 42.8^{\prime} \mathrm{S}, 72^{\circ} 38.4^{\prime} \mathrm{E} ; 57 \mathrm{~m}\right.$ a.s.l. $), 70 \mathrm{~km}$ southwest of the calving front, in a basal melt zone (Fig. 1). During the austral summer of 2001/02 a $479 \mathrm{~m}$ deep borehole was melted at site AM01 $\left(69^{\circ} 26.5^{\prime} \mathrm{S}, 71^{\circ} 25.0^{\prime} \mathrm{E} ; 65 \mathrm{~m}\right.$ a.s.I. $), 50 \mathrm{~km}$ westnorthwest of $\mathrm{AM02}, 90 \mathrm{~km}$ from the calving front. At AM01, hydraulic connection with the ocean cavity beneath the shelf was attained at $376 \mathrm{~m}$ depth, some $100 \mathrm{~m}$ above the base, indicating a highly porous or 'honeycomb' structure of the lowest layer of ice. At each site the boreholes were kept open for 5-7 days for scientific sampling, before mooring arrays were deployed for long-term monitoring. At AM01, depth-targeted ice-core samples were obtained using a HWD ice-coring head (Engelhardt and others, 2000) in an adjacent hole displaced $0.5 \mathrm{~m}$ from the access borehole.

\subsection{Sampling and monitoring instruments}

Measurement and sampling instruments deployed within and through the boreholes consisted of:

\section{1. borehole caliper and inclinometer}

2. hot-water drill ice-coring barrel (AM01 only)

3. Falmouth Scientific Instruments, FSI-3" Micro CTD (up and down casts)

4. Niskin water bottles

5. Aquadopp three-dimensional (3-D) acoustic current meter (AM01 only)

6. gravity sediment corer.

The caliper and inclinometer were used to check the integrity of the borehole for minimum diameter throughout, and verticality at exit into the ocean cavity below the shelf.

Ice-core analysis of the samples obtained from AM01 is the subject of ongoing investigation, with initial visual inspection, stable-isotope $\left(\delta^{18} \mathrm{O}\right)$, electrolytical conductivity, salinity and thin-section crystal-fabric analysis conducted inhouse thus far. 
The FSI CTD was pre-calibrated in a temperaturecontrolled water bath (Commonwealth Scientific and Industrial Research Organisation (CSIRO) Marine Laboratories, Hobart) prior to field deployment. During return voyages to Australia, aboard the research vessel Aurora Australis, it was intercalibrated with a ship-board CTD unit whilst mounted on a 12-bottle Niskin water-sampling rosette (Rosenberg and others, 2002). At AM02 the Niskin water samples were all contaminated due to a faulty housing arrangement causing leakage around the seals.

The Aquadopp 3-D acoustic current meter was used to record cavity current profiles beneath the AM01 site during $2 \mathrm{~min}$ stoppages at $20 \mathrm{~m}$ depth intervals over 30-40 min sample runs. A single extended 7 hour recording was also obtained from $477 \mathrm{dbar}$ (near the bottom of the well-mixed boundary layer; see section 4.3).

The gravity corer retrieved a clean $1.44 \mathrm{~m}$ long sediment core from the sea-floor at AM02 $(841 \mathrm{~m}$ below the ice-shelf surface), but failed to collect any significant sample at AM01 despite repeated attempts over several days (ice-shelf speed $800 \mathrm{~m} \mathrm{a}^{-1}$, spatial separation of 2-5 m). Sediment analysis procedures have been described elsewhere (Hemer and Harris, 2003).

Instruments for longer-term measurements were also deployed below, within and on the ice shelf at both sites. These consisted of:

1. three Seabird SBE-37-IM CTD units (pressure sensors failed at AM01)

2. strings of eight thermistors (ice/water interface, AM01 and AM02; ice internal AM01)

3. deep-ice thermistors at 80 and $150 \mathrm{~m}$ depth (AM02 only)

4. Benthos sonar altimeter (AM01 only)

5. surface automatic weather station (temperature, pressure, wind speed and direction, snow accumulation, near-surface snow temperature).

Problems were experienced with the thermistor string surface loggers, particularly at AM01 where the loggers failed in February-March 2002. The sonar altimeter at AM01 was positioned to look upwards at the base of the shelf from $20 \mathrm{~m}$ below, but, after initially providing good data, this instrument failed to provide measurements of basal freeze or melt rates at the site.

\section{RESULTS AND INTERPRETATION}

\subsection{Basal melt/freezing rates}

Thermistor measurements within the body of the ice shelf and toward the ice/water interface at AM02 were typical of those at a basal melt site, with a minimum internal temperature of $-20.3^{\circ} \mathrm{C}$ at $80 \mathrm{~m}$, increasing monotonically to the pressure-freezing temperature at the base, $-2.12^{\circ} \mathrm{C}$ at $373 \mathrm{~m}$. The closely spaced thermistors across the interface have not yet yielded a clear mean annual melt rate, but from their spacing the upper limit is $2 \mathrm{ma}^{-1}$. The lower limit can be estimated from considerations of the conservation of heat and salt for the static stability of a meltwater-modified boundary layer immediately beneath the shelf (Jacobs and others, 1979).

$$
\frac{\Delta T}{\Delta S}=\frac{\rho_{\mathrm{i}} m L+K_{\mathrm{i}}\left(\frac{\Delta T_{i}}{\Delta z}\right)}{C_{p}\left[\rho_{\mathrm{i}} m S-K_{\mathrm{v}}\left(\frac{\Delta S_{\mathrm{v}}}{\Delta z}\right)\right]}
$$

The temperature gradient $\left(\Delta T_{\mathrm{i}} / \Delta z\right)$ in the bottom few metres of the shelf was measured to be $0.17^{\circ} \mathrm{C} \mathrm{m}^{-1}$, compared to $0.08^{\circ} \mathrm{C} \mathrm{m}^{-1}$ at the 19 borehole site on the Ross Ice Shelf (Jacobs and others, 1979). The salinity gradient $\left(\Delta S_{\mathrm{v}} / \Delta z\right)$ below the boundary layer was found from CTD casts (see section 4.3) to be $0.00043 \mathrm{~m}^{-1}$ (compared to $0.0025 \mathrm{~m}^{-1}$ at J9). With the latent heat of fusion, $L=3.35 \times 10^{5} \mathrm{~J} \mathrm{Kg}^{-1}$; seawater thermal capacity, $C_{\mathrm{p}}=4 \times 10^{3} \mathrm{~J} \mathrm{Kg}^{-1} \mathrm{~K}^{-1}$; representative salinity, $S=34.4$; thermal conductivity of ice, $K_{\mathrm{i}}=2.2 \mathrm{~J} \mathrm{~s}^{-1}$ $\mathrm{m}^{-1} \mathrm{~K}^{-1}$; ice density, $\rho_{\mathrm{i}}=9.17 \times 10^{10} \mathrm{~kg} \mathrm{~m}^{-3}$; a coefficient of vertical turbulent mixing (not well known) for the halocline beneath the boundary layer, $K_{\mathrm{v}}=0.1 \mathrm{Kg} \mathrm{m}^{-1}$; and a ratio of temperature to salinity change equal to the local isopycnal gradient, $\Delta T / \Delta S=32$; a minimum melt rate, $m=0.5 \mathrm{~m} \mathrm{a}^{-1}$ was obtained. Net mean melt rates in the $0.5-2.0 \mathrm{~m} \mathrm{a}^{-1}$ range are considered reasonable for such a site within $100 \mathrm{~km}$ of the ice-shelf calving front where tidal pumping and seasonally warmer waters of the coastal current penetrate the front part of the shelf cavity to shallow depth (Jenkins and Doake, 1991; Jacobs and others, 1992).

Despite problems encountered with thermistor strings at AM01, initial data indicate that the temperature profile has an inflection curve typical of basal accretion sites, and in agreement with measurements from a 1968 ice-core borehole to $315 \mathrm{~m}$ depth taken at the same geographic location (Morgan, 1972). The lower $150 \mathrm{~m}$ of marine ice (see section 4.2) in the shelf may be an almost isothermal layer near the basal in situ sea-water freezing temperature $\left(-2.23^{\circ} \mathrm{C}, 34.40 \mathrm{PSS} 78,440 \mathrm{dbar}\right)$ as might be expected from the high porosity evidenced by the hydraulic connection $100 \mathrm{~m}$ above the ice-shelf base during drilling. No estimate is available yet of possible accretion rates from either the interface thermistor string or the upward-looking sonar altimeter deployed at this site.

\subsection{Marine-ice properties}

A HWD ice-coring head (Engelhardt and others, 2000) was trialled at AM01, primarily to sample marine ice at depth. The meteoric-/marine-ice interface was anticipated to be around $270 \mathrm{~m}$ depth, from analysis of the earlier $315 \mathrm{~m}$ core (Morgan, 1972). HWD ice-core samples were collected from $240 \mathrm{~m}$, within the meteoric ice; $290 \mathrm{~m}$, near the top of the marine ice; and 360 and $390 \mathrm{~m}$, just above and below the hydraulic connection depth. The marine ice from $290 \mathrm{~m}$ contained debris bands that from $360 \mathrm{~m}$ had a bubble structure (possibly brine pockets), and the lowest sample was highly porous honeycomb ice. As this was a first attempt at HWD ice coring and field fuel stocks were low, techniques were not perfected, so that the ice cores collected were not uniformly cylindrical, but quite irregular in shape, particularly at depth. In 2002/03 a Polar Research Institute of China core-drilling team recovered a $302 \mathrm{~m}$ long continuous ice core at a site within $100 \mathrm{~m}$ of AM01 and detected the marine-ice interface at $276 \mathrm{~m}$ by visual inspection of the core (sharp transition from bubbly meteoric to clear marine ice with debris inclusions) (personal communication from Li Yuansheng, 2003).

Marine ice from reasonably thick layers $(60 \mathrm{~m}$ or more) was reported earlier to be devoid of brine drainage channels and bubbles (Oerter and others, 1992). Previously measured anomalously low marine-ice electrolytical conductivities $\left(40-200 \mu \mathrm{S} \mathrm{cm}^{-1}\right)$ in the Ronne and Amery Ice Shelves could not be explained by typical sea-ice brine drainage mechanisms (gravity drainage and brine pore migration). A frazil-ice 


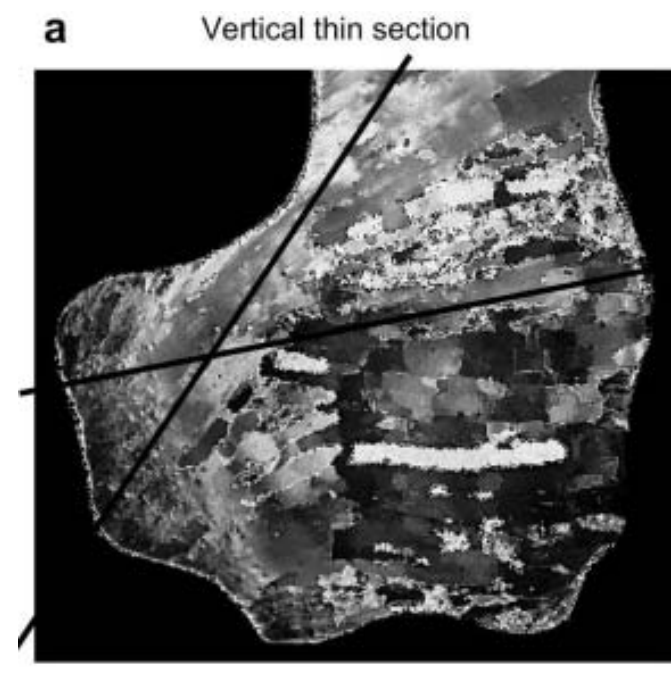

C

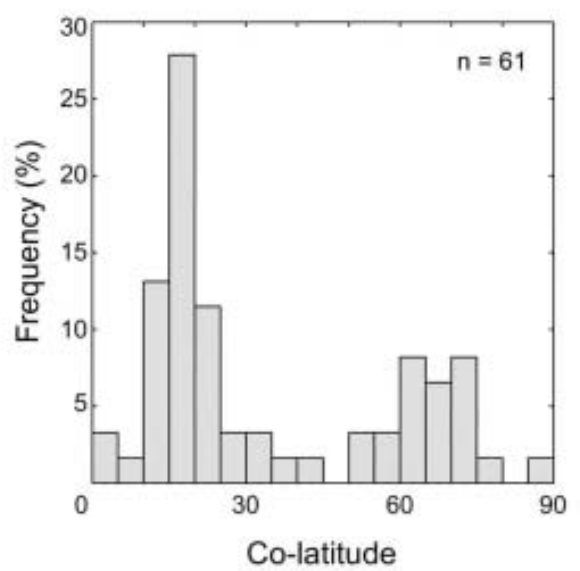

b Horizontal thin section

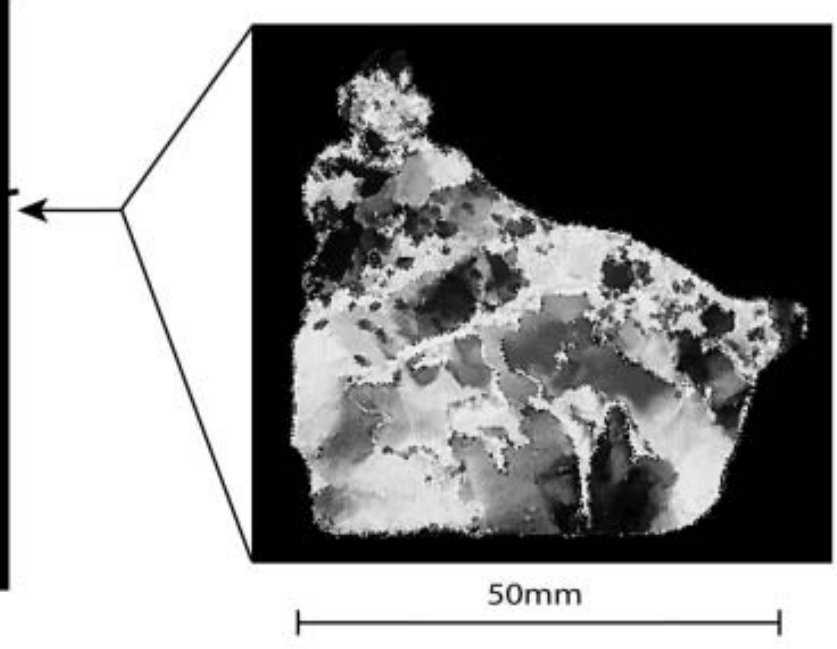

d Schmidt Equal Area Plot

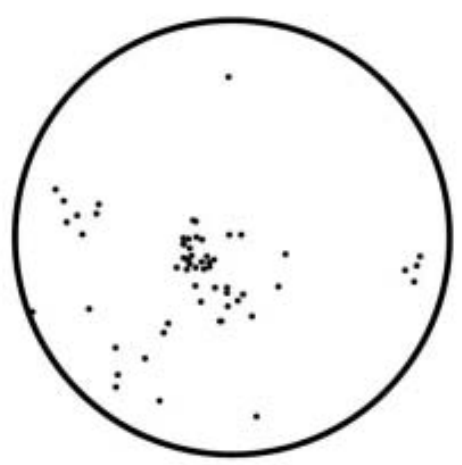

Fig. 3. Vertical (a) and horizontal (b) thin sections with crystal-orientation histogram (c) and fabric diagram (d) of porous marine ice from $390 \mathrm{~m}$ depth at AM01.

compaction mechanism consisting of two stages - individual crystal formation in the water column, followed by compaction and consolidation at the base of the ice shelf-rather than in situ ice growth has been proposed for production of the layers (Engelhardt and Determann, 1987; Eicken and others, 1994; Tison and others, 2001).

Oxygen isotope $\left(\delta^{18} \mathrm{O}\right)$, electrolytical conductivity, and salinity data for the AM01 core samples are shown in

Table 1. Mean stable oxygen isotope $\left(\delta^{18} \mathrm{O}\right)$, electrolytical conductivity, and salinity values for ice-core samples from AM01 (number of samples in parentheses)

\begin{tabular}{cccc}
\hline Core depth & $\delta^{18} \mathrm{O}$ & $\begin{array}{c}\text { Electrolytical } \\
\text { conductivity } \\
\mu \mathrm{Cm}^{-1}\end{array}$ & $\begin{array}{c}\text { Salinity } \\
\text { (PSS78) }\end{array}$ \\
$\mathrm{m}$ & $\%$ o & & \\
\hline 240 & $-36.9(19)$ & $20.3(2)$ & $0.015(1)$ \\
$240(1972)$ & -36.4 & 4 to 18 & - \\
290 & $+2.0(22)$ & $90.2(2)$ & $0.059(1)$ \\
$290(1972)$ & +0.9 to +1.5 & 100 to 190 & - \\
360 & $+1.0(19)$ & $380(2)$ & $0.575(1)$ \\
390 & $-0.6(11)$ & $1410(2)$ & $0.754(2)$ \\
\hline
\end{tabular}

Table 1. In the upper marine-ice layer (290 m depth) a $\delta^{18} \mathrm{O}$ value of $+2 \%$ was found (in agreement with Morgan, 1972) decreasing to $-0.6 \%$ at $390 \mathrm{~m}$ (cf. mean value $-0.76 \%$ in the sea-water column). The fractionation of the lowest layers of AIS marine ice is smaller than that previously found for thick marine-ice layers on the Ronne Ice Shelf (Oerter and others, 1992; Eicken and others, 1994). Comparatively high electrolytical conductivity and salinity values in the deep samples (0.575 PSS78 at $360 \mathrm{~m}$, and 0.752 PSS78 at $390 \mathrm{~m}$ ) also contrast with typically decreasing conductivity and salinity with depth in consolidated marine ice devoid of brine inclusions on the Ronne Ice Shelf (Oerter and others, 1992; Eicken and others, 1994; Moore and others, 1994). Such values are in striking agreement, however, with the salinity range quoted for marine ice from shallow-depth $(45 \mathrm{~m})$ core samples collected from Hells Gate Ice Shelf (HGIS) (Tison and others, 1998). At HGIS the more positive $\delta^{18} \mathrm{O}$ signature of the marine ice collected from near the front of the shelf was interpreted as an indication of recycling of melted marine ice from upstream. It is possible that the decrease of $\delta^{18} \mathrm{O}$ with depth at AM01 reflects an increased contribution of melted meteoric ice (e.g. from the eastern part of the AIS) to the parent water.

A vertical thin section of the porous core sample at $390 \mathrm{~m}$ through crossed polarizing filters shows bands of rectangular 

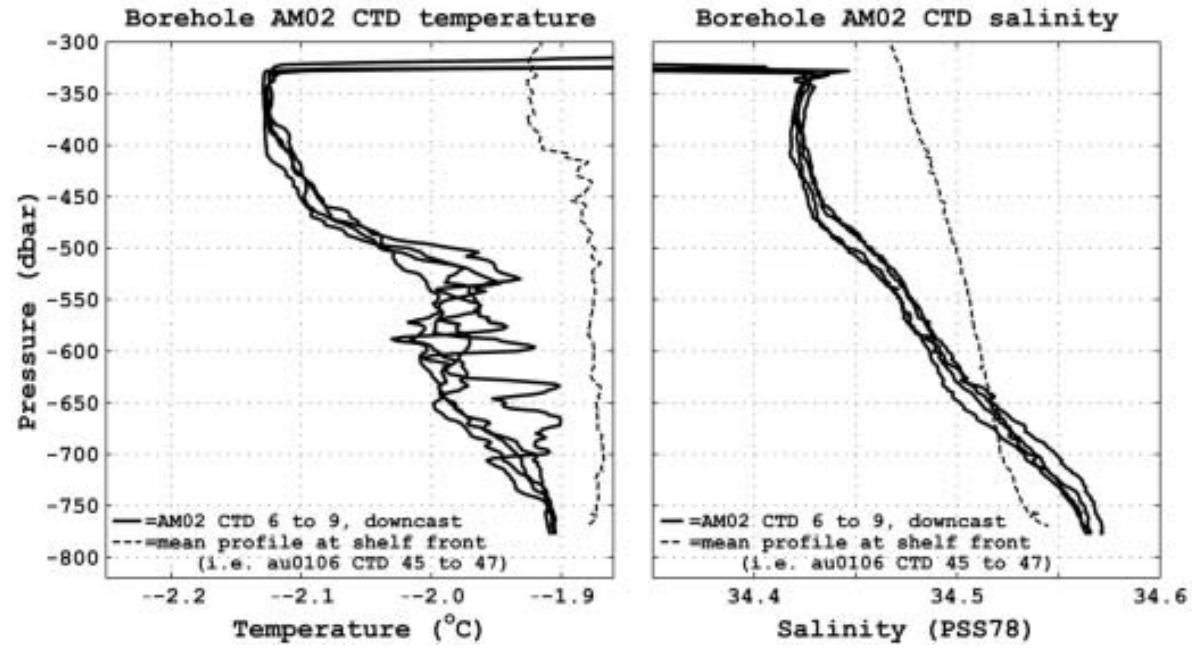

Fig. 4. CTD data profiles in the $468 \mathrm{~m}$ deep ocean cavity beneath the ice shelf at AM02, January 2001. Also shown is a representative mean profile (dashed line) at equivalent depths in the water column out front of the shelf (measured 4 weeks later).

crystals (Fig. 3a). The fabric diagram of a corresponding horizontal thin section (Fig. 3b) shows a strong single pole near vertical maximum, and a small offset arc at $60-75^{\circ}$ (Fig. 3c and d). This can be interpreted from the vertical thin section as due to two preferred directions of rectangular crystals, which likely formed as two separate clumps, later welded together into the marine-ice matrix at an angle relative to one another. As shown by Tison and others (1993), the textural and structural characteristics are typical of the more saline marine ice at HGIS. These authors suggested that the strongly aligned $c$-axes fabrics in marine ice are indicative of individual frazil crystals orienting nearly parallel to the ice/ocean interface during initial freezing under the influence of boundary layer currents. The horizontal layering of the banded rectangular facies described here is in contrast to the near-vertical orientation of similar crystals in marine ice recovered from near the grounding line of the Nansen Ice Shelf (NIS). The NIS marine ice, however, formed in large basal crevasses and had subsequently undergone significant folding due to high lateral compression (Khazendar and others, 2001).

Relatively shallow ocean circulation, in which ice-shelf water (ISW) (see section 4.3) production, and marine-ice accretion took place, led to the formation of similarly highsalinity (>0.5 PSS78) banded marine-ice facies in the frontal zone of HGIS. This had been considered a peculiar process, perhaps unique (Tison and others, 1998), with until now no deep marine-ice cores collected from the major ice shelves exhibiting this textural type. At HGIS, sea water began to enter the air-filled drillhole at $32 \mathrm{~m}$ depth (total core length $45 \mathrm{~m}$ ), indicating the lower banded facies of the marine ice was highly permeable, with interstitial water salinity enriched by brine exclusion through active freezing during the consolidation process (Tison and others, 1998). At AM01 the hydraulic connection realized with the HWD head at $376 \mathrm{~m}$ depth (100 m up from the shelf base) was the result of the pressure head exerted by a $320 \mathrm{~m}$ long water column within the borehole punching through highly permeable bandedfacies marine ice deep down. No direct evidence exists of basal melting or freezing at this site, although phase changes are highly likely at least within the banded facies 'host' water matrix (Tison and others, 2001), even if not at the very base of the shelf. There was no clear evidence of significant frazil ice, or slush build-up toward the base of the borehole, with no resistance to the passage of instruments in or out.

Debris inclusions within the marine-ice core samples are yet to be analyzed, but during HWD ice-core sampling trials at AM01 the core dog inserts of the core barrel returned to the surface from around $360 \mathrm{~m}$ depth full of debris that had been melted out of the borehole walls. This debris consisted of two fractions. The first was pale grey, fine and coherent siliceous mud and ooze (SMO) containing the diatom Fragilariopsis curta, whose presence represents either advection in marine water, or a piece of sediment from some relatively recent time when the ice edge was further south (personal communication from P. Quilty and A. McMinn, 2002). The remainder of the sediment consisted of angular sand grains of such size as should not remain suspended in the water column for any significant length of time. An ice-shelf flowline traced upstream from the AM0.1 borehole passes close to Budd Ice Rumples (BIR; $71^{\circ} 30^{\prime} \mathrm{S}$, $68^{\circ} 45^{\prime} \mathrm{E}$; see Fig. 1) where bedrock projects halfway into the local 800-900 m ice-shelf thickness. The BIR and the more northerly Else Platform-Jetty Peninsula region are suggested as possible sources of granular debris incorporated into the accreted marine-ice layer sampled at AM01.

\subsection{Ocean structure beneath the ice shelf}

CTD profiles measured in the $468 \mathrm{~m}$ deep water column beneath the northeastern site AM02 revealed a characteristic cool fresh layer $\left(-2.12^{\circ} \mathrm{C}, 34.42\right.$ PSS78, $\left.330 \mathrm{dbar}\right)$ indicative of a meltwater-modified boundary layer in the upper 40$60 \mathrm{~m}$ immediately beneath the shelf, where the pressurefreezing point at the ice-shelf base is $-2.13^{\circ} \mathrm{C}$ (Fig. 4). A number of persistent intrusions of warmer water were seen below the thermocline, whilst salinity increased steadily toward the seabed $\left(-1.90^{\circ} \mathrm{C}, 34.54\right.$ PSS78, $\left.770 \mathrm{dbar}\right)$. Openocean CTD profiles measured off the front of the shelf (1 month later) showed water temperatures close to $-1.9^{\circ} \mathrm{C}$ throughout that part of the water column equivalent to depths in the cavity beneath AM02. Salinities at $330 \mathrm{dbar}$ (the depth of the base of the shelf at AM02) were in the range 34.46-34.48 PSS78, slightly above those found in the iceshelf basal boundary layer. But the salinity at $770 \mathrm{dbar}$ was almost the same as found near the sea-floor beneath the borehole site. 
Borehole AM01 CTD temperature

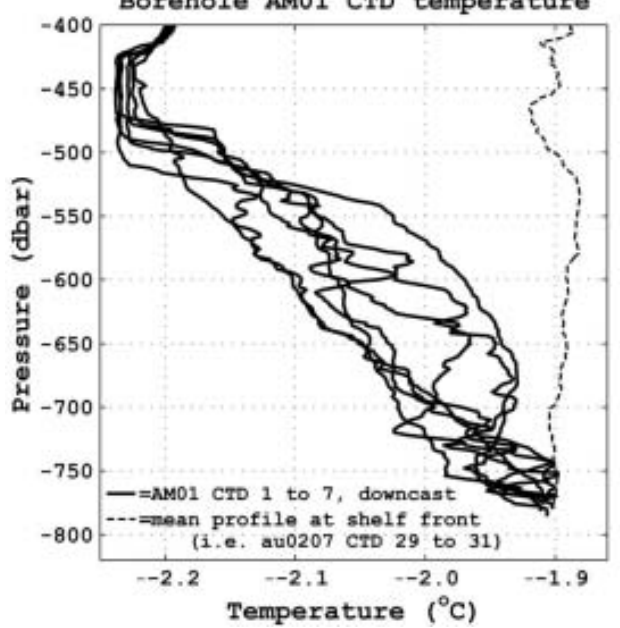

Borehole AM01 CTD salinity

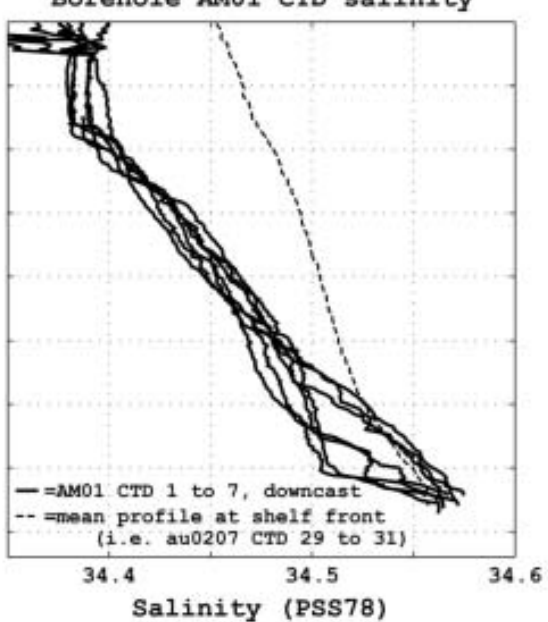

Fig. 5. CTD data profiles in the $362 \mathrm{~m}$ deep ocean cavity beneath the ice shelf at AM01, January 2002. Also shown is a representative mean profile (dashed line) at equivalent depths in the water column out front of the shelf (measured 2 weeks later).

Summertime ocean structure in the $360 \mathrm{~m}$ deep water column at the central site AM01 (Fig. 5) was similar to that for AM02, but with a thicker $(80-100 \mathrm{~m})$, cooler boundary layer at greater depth $\left(-2.23^{\circ} \mathrm{C}, 34.40\right.$ PSS78, $\left.420 \mathrm{dbar}\right)$. The upper $50 \mathrm{~m}$ of this layer was slightly supercooled compared to the pressure-freezing temperature of $-2.20^{\circ} \mathrm{C}$ (data quality in temperature and salinity measurements both considered good to within \pm 0.005 units, pressure to \pm 2 dbar), indicating a potential for frazil formation at the base of the shelf. Open-ocean water-column properties off the front of the shelf were similar to those found downstream of AM02.

An almost complete annual record for 2001 was recovered from CTD instruments moored at three depths in the water column beneath AM02. Data from the uppermost instrument, suspended some $20 \mathrm{~m}$ below the ice-shelf base ( $338 \mathrm{dbar}$ ), are shown in a potential-temperature-salinity $(\theta-S)$ diagram in Figure 6 . This depicts an anticlockwise seasonal cycle of water-mass characteristics. From summer through to winter there is a warming and slight freshening driven by intrusion of water from Prydz Bay. This water has characteristics (Wong and others, 1998) of a mix of Winter Water $\left(\mathrm{WW} ;-1.9^{\circ} \mathrm{C}<\theta<-1.5^{\circ} \mathrm{C}, 34.2\right.$ $\leq S \leq 34.5$ PSS78) and Summer Surface Water (SSW; $\left.-1.8^{\circ} \mathrm{C}<\theta<-2.1^{\circ} \mathrm{C}, \quad 30.6 \leq S \leq 34.2 \mathrm{PSS} 78\right)$. From winter to spring, ice-shelf basal melt causes freshening and cooling, producing Ice Shelf Water (ISW, $\theta<-2^{\circ} \mathrm{C}$ ). The winter gradient $(\Delta \theta / \Delta S \approx 2.5)$ approximates the slope of the adiabatic melt-freeze curve (Gade, 1979), and yields a winter melt rate equivalent to around $3 \mathrm{~m} \mathrm{a}^{-1}$ from Equation (1), although the salinity gradient $\left(\Delta S_{v} / \Delta z\right)$ below the boundary layer is not well known. The lowest salinity values recorded require a slight broadening of ISW definition for this region down to 34.25 PSS78, with even lower values expected at greater depth beneath the ice shelf. A gradual increase in salinity, tied to the pressure-freezing point at the base of the ice shelf, occurred through spring into early summer as more saline water from sea-ice formation and brine-rejection processes in Prydz Bay entered the cavity. In this part of Prydz Bay, salinities did not attain values as high as those in what is called High Salinity Shelf Water (HSSW; $S<34.6$ PSS78) in the Weddell Sea, and therefore are unlikely to contribute to bottom water formation (Carmack,
1986). Initial CTD data from moorings at similar depths in the water column at the front of the shelf showed a corresponding anticlockwise seasonal cycle.

Limited data are available from a current meter deployed through the borehole at site AM01. These measurements indicated currents of around $5 \mathrm{~cm} \mathrm{~s}^{-1}$ inflow immediately beneath the shelf, and stronger $5-10 \mathrm{~cm} \mathrm{~s}^{-1}$ outflow near the sea-floor. One continuous 7 hour recording was obtained at $477 \mathrm{dbar}$ (approximate position of the thermocline) with a $5-10 \mathrm{~cm} \mathrm{~s}^{-1}$ inflow swinging slowly over the first 3 hours to a steady outflow for the remainder of the record. Moored ADCP measurements off the front of the ice shelf yielded monthly mean currents for 2001 for positions downstream of both the AM01 and AM02 boreholes. For the basal-melt AM02 site, shelf front currents at depths equivalent to the ice-shelf base at AM02 were chiefly outflowing from March to October, and with a weak inflow through to February.

\subsection{Sea-floor sediments}

Included in the AMISOR project objectives is the derivation of a long-term sediment record of the time variability of the interaction between the ocean and the AIS, and to understand the implications of this for the discharge of grounded ice and for water-mass modification. For this purpose, a $1.5 \mathrm{~m}$ long, $0.1 \mathrm{~m}$ diameter gravity sediment corer was deployed at the borehole sites. Hemer and Harris (2003) present the analysis from the collected sub-ice-shelf sediments. A summary of their results is included here to complete an overview of all collected borehole data.

A single $1.44 \mathrm{~m}$ long sediment core was obtained from the sea-floor at a depth of $841 \mathrm{~m}$ below the ice-shelf surface (57 m a.s.l.) at AM02, some $70 \mathrm{~km}$ southwest of the calving front (Fig. 7). The upper third of the core was Holocene-age siliceous mud and diatom ooze (SMO) of marine origin (Hemer and Harris, 2003) which is typical of continentalshelf deposits (Dunbar and others, 1985). This is supporting evidence for transport by currents under the shelf from Prydz Bay. Immediately below this was an olive-grey, well-sorted, massively bedded, very fine-grained silt, low in biogenic opal and carbonaceous material, overlying glacial till containing several large clasts $(3-5 \mathrm{~cm}$ diameter $)$, both 


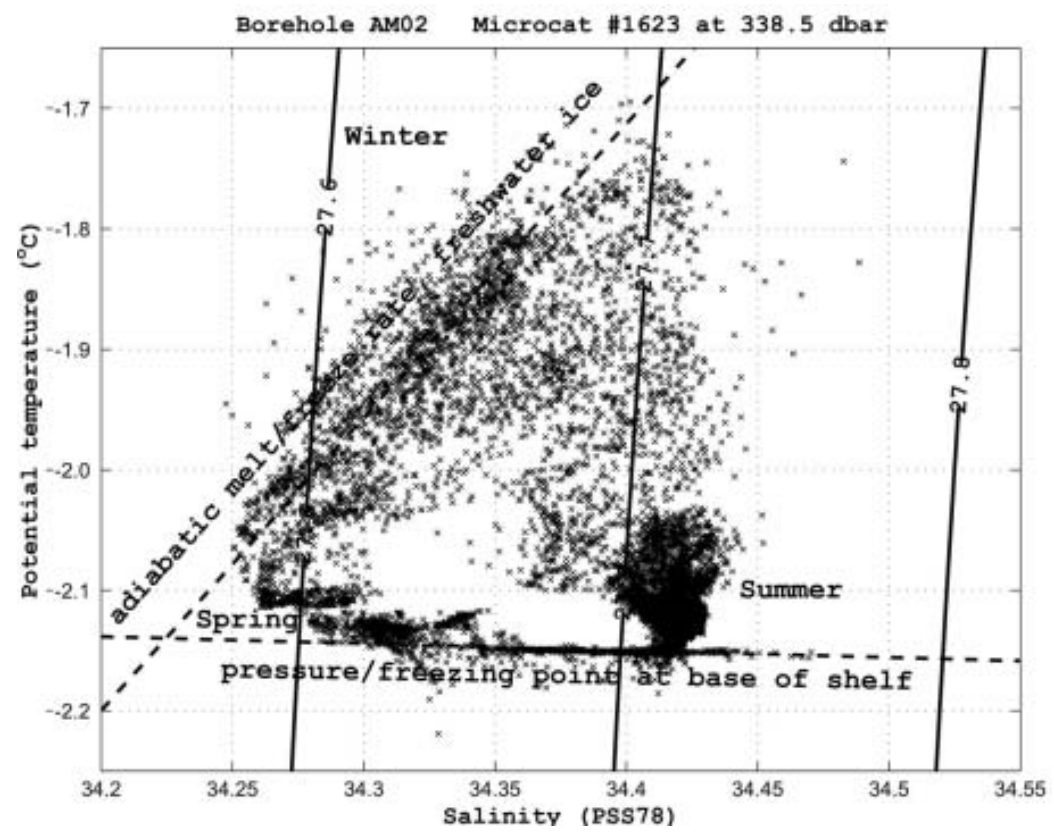

Fig. 6. Potential-temperature vs salinity diagram for 2001 from the upper CTD instrument $(P=338 \mathrm{dbar})$ at the AM02 site. Water-mass characteristics show seasonal variability which follows an anticlockwise cycle in $(\theta-S)$ space.

interpreted as water-lain deposits formed rapidly proximal to a palaeo grounding zone. These overlaid a lodgement till in the last few centimetres of the core, deposited during the Last Glacial Maximum. There was evidence for an increase in deposition of sea-ice-associated diatoms (Fragilariopsis curta) around 3500-5000 years $\mathrm{BP}$, suggestive of a major retreat of the AIS front during the mid-Holocene climatic optimum (Hemer and Harris, 2003). Alternatively, with warmer ocean temperatures, modelling studies predict stronger currents and therefore greater biogenic transport beneath the ice shelf (Hemer, 2003), while increased sea-ice biogenic productivity may also play a role.

At AM01 no sediment core was obtained despite repeated attempts, due likely to the highly compacted nature of the seabed. However, small sediment scrape samples were obtained from around the core barrel, indicating an uncorrected surface ${ }^{14} \mathrm{C}$ age $(11722 \pm 60$ years BP $)$ nearly twice that of the surface layer age at the AM02 basal melt site $(6548 \pm 60$ years BP). This could be interpreted as a consequence of the under-ice ocean circulation pattern wherein this site was in a predominantly outflow regime, compared to an inflow regime at the basal melt site; or alternatively may reflect sediment starvation during the Holocene at this site (Hemer and Harris, 2003).

\section{SUMMARY AND CONCLUSIONS}

We have examined two boreholes with different basal regimes, one with active melt (AM02) and the other with a considerable thickness of accreted marine ice (AM01). At the melt site, mean net basal melt rates are estimated to be $0.5-2.0 \mathrm{~m} \mathrm{a}^{-1}$, with possible winter melt rates up to $3 \mathrm{~m} \mathrm{a}^{-1}$. At the marine-ice site, basal change rates remain as yet undetermined, though a potential for local frazil-ice formation has been observed.

The marine-ice layer at AM01 has been found to be close to $200-210 \mathrm{~m}$ thick. This compares well with an early estimate of $196 \mathrm{~m}$ inferred from hydrostatic equilibrium considerations (Morgan, 1972), and is larger than the $141 \pm 30 \mathrm{~m}$ derived estimate from satellite altimeter measurements (Fricker and others 2001). The major sources of error in the altimetry method result from rms errors in the digital elevations, uncertainties in geoid-ellipsoid separations, ice radar limitations, and uncertainties in the adopted ice-shelf density model. Future laser altimetry studies, better coherentphase radio-echo sounding results, gravity surveys, and adjustments to the density model will all improve mapping of the marine-ice layer distribution pattern for the region.

In at least the upper region of the marine-ice layer at AM01 the very low-salinity (0.059 PSS78), bubble-free, debris-enriched, consolidated ice has similar characteristics to those reported previously for the Amery (Morgan, 1972) and Filchner-Ronne (Oerter and others, 1992; Eicken and others, 1994; Moore and others, 1994) Ice Shelves. Coarse granular particulate debris incorporated into this upper layer may result from marine-ice formation in the shallow cusp regions between where ice streams merge northwards of Else Platform-Jetty Peninsula, and after grounded shelf

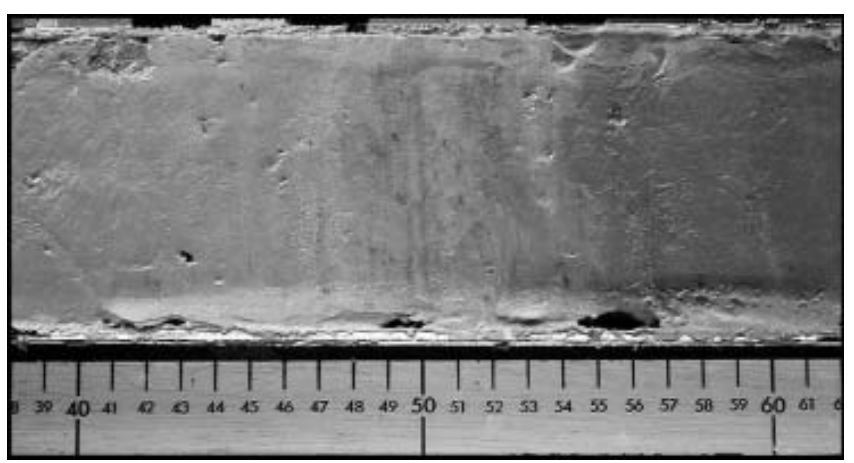

Fig. 7. AM02 sediment sample showing transition between the SMO layer and the non-biogenic water-lain layers down-core, at around $50 \mathrm{~cm}$ depth. (Some iron-oxide-rich laminations are evident near the transition region.) 
contact with Budd Ice Rumples. The estimated AIS marineice distribution map (Fricker and others, 2001) indicates that the layer thickness increases dramatically immediately north of Else Platform, implying possible accelerated production rates in that region. Sub-shelf geometry between merging ice streams of different thicknesses may play an important role in this process.

A surprising aspect of the marine-ice properties at AM01 was the honeycomb nature of the ice at depth, probably extending through the entire lower $100 \mathrm{~m}$ of the layer. The highly porous nature of this ice, with brine pockets, increased salinities, reduced oxygen isotope fractionation, and rectangular banded-facies textural characteristics, is almost identical to the marine ice collected from HGIS (Tison and others, 1998). By analogy to the HGIS interpretation, where two distinct marine-ice production mechanisms were proposed, it is supposed that the upper consolidated marine ice at AM01 results from ISW formed by deep thermohaline convection circulation and melting near the grounding zone (Jacobs and others, 1992), the mechanism responsible for marine ice reported from under the Ronne Ice Shelf (Nicholls and others, 1991). The lower permeable banded-facies marine ice likely forms from a shallower-depth circulation loop toward the front of the shelf, producing ISW that reaches the pressure-melting point at some greater depth, then achieves a state of supercooling during the return flow elsewhere beneath the shelf (Tison and others, 1998).

The temperature profile in the upper meteoric ice at AM01 has an inflection point characteristic of a basal freezing site, with the lower 100-150 m of accreted marine ice there an almost isothermal layer near the local sea-water pressure-freezing point. Together with the honeycomb nature of the ice, this may make this region of the shelf particularly vulnerable to changes in character of water masses that penetrate the ocean cavity below, and may also dramatically increase initial iceberg dissolution rates in Prydz Bay for icebergs containing this layer.

Summertime ocean structure beneath the AIS at both borehole sites consists of an upper boundary layer of ISW above the thermocline, whilst near the sea-floor water-mass characteristics mirror those at similar depths in the open ocean out front of the shelf, where temperatures are close to the surface freezing point throughout the equivalent water column.

Water-mass characteristics in the ocean cavity beneath AM02 show a strong seasonal dependence, with relatively warm surface water from out front of the shelf being strongly modified by basal melting throughout winter into ISW at the local pressure-freezing point. Changes in Prydz Bay circulation patterns as a result of climate warming, with stronger current fluxes entering the shelf cavity (Hemer, 2003), may lead to a significant increase in basal melt rates toward the front of the shelf. Such destabilization may in part be offset by accompanying increases to banded-facies marine-ice formation elsewhere. Less intense winter sea-ice production, also as a result of climate warming, could lead to a reduction in deep thermohaline convection fluxes, reducing basal melt rates near the grounding zone (Nicholls, 1997). This may lead to an ice-shelf profile with an overall steeper gradient, with much thicker ice upstream and thinner ice toward the front. From a dynamics point of view, this would have considerable consequences for shelf advance, spreading, and iceberg calving rates. For the Filchner-Ronne it has been argued that the predominant source of ISW production is melting toward the front of the ice shelf (Joughin and Padman, 2003). This is yet to be fully determined for the AIS, though the study presented here indicates that at least some ISW formation is indeed occurring within $100 \mathrm{~km}$ of the calving front.

\section{ACKNOWLEDGEMENTS}

The authors wish to acknowledge the support of the many personnel from ANARE (Australian National Antarctic Research Expeditions), Australian Antarctic Division, and University of Tasmania Antarctic CRC who have assisted with the preparation, deployment and operation of the AMISOR project. We are particularly indebted to camp manager R. Baldwin, diesel mechanics $N$. Jones and A. Drinkell, and glaciologist D. Thost for their contributions in the field. K. Nicholls and K. Makinson of the British Antarctic Survey, K. Echelmeyer of the Geophysical Institute of Alaska, and J. Luthiger of the Eidgenössische Technische Hochschule Zürich provided detailed advice and descriptions of their HWD systems, much of which was incorporated into our own HWD design and construction. $H$. Engelhardt kindly supplied blueprints and gave specific advice on hot-water ice-coring barrel design and operation. Oceanographic instruments were prepared and calibrated by CSIRO Marine Research in Hobart, with recalibration factors determined and applied by M. Rosenberg of Antarctic CRC. Salinity samples were measured by C. Curran of Antarctic CRC. Initial ice-shelf front oceanographic mooring analyses were provided by $\mathrm{H}$. Leffanue. Constructive reviews by J.-L. Tison and G. Giorgetti greatly improved the manuscript.

\section{REFERENCES}

Allison, I. 1979. The mass budget of the Lambert Glacier drainage basin, Antarctica. J. Glaciol., 22(87), 223-235.

Browning, J. A., R. A. Bigl and D. A. Sommerville. 1979. Hot-water drilling and coring at site J-9, Ross Ice Shelf. Antarct. J. US, 14(5), 60-61.

Budd, W. 1966. The dynamics of the Amery Ice Shelf. J. Glaciol., 6(45), 335-358.

Budd, W. F., M. J. Corry and T. H. Jacka. 1982. Results from the Amery Ice Shelf Project. Ann. Glaciol., 3, 36-41.

Carmack, E. C. 1986. Circulation and mixing in ice-covered waters. In Untersteiner, N., ed. Geophysics of sea ice. London, etc., Plenum Press, 641-712. (NATO ASI Series B: Physics 146.)

De Angelis, H. and P. Skvarca. 2003. Glacier surge after ice shelf collapse. Science, 299(5612), 1560-1562.

Domack, E. W. and 6 others. 1998. Late Quaternary sediment facies in Prydz Bay, East Antarctica and their relationship to glacial advance onto the continental shelf. Antarct. Sci., 10(3), 236-246.

Dunbar, R. B., J. B. Anderson and E.W. Domack. 1985. Oceanographic influences on sedimentation along the Antarctic continental shelf. In Jacobs, S.S., ed. Oceanology of the Antarctic continental shelf. Washington, DC, American Geophysical Union, 291-312. (Antarctic Research Series 43.)

Eicken, H., H. Oerter, H. Miller, W. Graf and J. Kipfstuhl. 1994. Textural characteristics and impurity content of meteoric and marine ice in the Ronne Ice Shelf, Antarctica. J. Glaciol., 40(135), 386-398.

Engelhardt, H. and J. Determann. 1987. Borehole evidence for a thick layer of basal ice in the central Ronne Ice Shelf. Nature, 327(6120), 318-319.

Engelhardt, H., N. Humphrey, B. Kamb and M. Fahnestock. 1990. Physical conditions at the base of a fast moving Antarctic ice stream. Science, 248(4951), 57-59. 
Engelhardt, H., B. Kamb and R. Bolsey. 2000. A hot-water icecoring drill. J. Glaciol., 46(153), 341-345.

Foldvik, A. and T. Gammelsrød. 1988. Notes on Southern Ocean hydrography, sea-ice and bottom water formation. Palaeogeogr., Palaeoclimatol., Palaeoecol., 67(1-2), 3-17.

Fricker, H. A., S. Popov, I. Allison and N. Young. 2001. Distribution of marine ice under the Amery Ice Shelf, East Antarctica. Geophys. Res. Lett., 28(11), 2241-2244.

Fricker, H.A., N.W. Young, I. Allison and R. Coleman. 2002a. Iceberg calving from the Amery Ice Shelf, East Antarctica. Ann. Glaciol., 34, 241-246.

Fricker, H. A. and 9 others. 2002b. Redefinition of the Amery Ice Shelf, East Antarctica, grounding zone. J. Geophys. Res., 107(B5) (10.1029/2001JB000383.)

Gade, H. G. 1979. Melting of ice in sea water: a primitive model with application to the Antarctic ice shelf and icebergs. J. Phys. Oceanogr., 9(1), 189-198.

Hemer, M.A. 2003. The oceanographic influence of sedimentation on the continental shelf: a numerical comparison between tropical and Antarctic environments. $(\mathrm{PhD}$, Institute of Antarctic and Southern Ocean Studies, University of Tasmania.)

Hemer, M. A. and P. T. Harris. 2003. Sediment core from beneath the Amery Ice Shelf, East Antarctica, suggests mid-Holocene iceshelf retreat. Geology, 31(2), 127-130.

Humphrey, N. and K. Echelmeyer. 1990. Hot-water drilling and bore-hole closure in cold ice. J. Glaciol., 36(124), 287-298.

Iken, A., K. Echelmeyer and W. D. Harrison. 1989. A light-weight hot water drill for large depth: experiences with drilling on Jakobshavns glacier, Greenland. In Rado, C. and D. Beaudoing, eds. Ice core drilling. Proceedings of the Third International Workshop on Ice Drilling Technology, Grenoble-France, 10-14 October 1988. Grenoble, Centre National de la Recherche Scientifique. Laboratoire de Glaciologie et Géophysique de I'Environnement, 123-136.

Jacobs, S. S., A. L. Gordon and J. L. Ardai, Jr. 1979. Circulation and melting beneath the Ross Ice Shelf. Science, 203(4379), 439-443.

Jacobs, S.S., H.H. Hellmer, C.S.M. Doake, A. Jenkins and R. M. Frolich. 1992. Melting of ice shelves and the mass balance of Antarctica. J. Glaciol., 38(130), 375-387.

Jenkins, A. and C.S.M. Doake. 1991. Ice-ocean interaction on Ronne Ice Shelf, Antarctica. J. Geophys. Res., 96(C1), 791-813.

Joughin, I. and L. Padman. 2003. Melting and freezing beneath Filchner-Ronne Ice Shelf, Antarctica. Geophys. Res. Lett., 30(9), 1477-1480. (10.1029/2003GL016941.)

Khazendar, A., J.-L. Tison, B. Stenni, M. Dini and A. Bondesan. 2001. Significant marine-ice accumulation in the ablation zone beneath an Antarctic ice shelf. J. Glaciol., 47(158), 359-368.

Koci, B. R. 1984. Hot water drilling in Antarctic firn, and freezing rates in water-filled boreholes. CRREL Spec. Rep. 84-34, 101-103.

Makinson, K. 1993. The BAS hot water drill: development and current design. Cold Reg. Sci. Technol., 22(1), 121-132.
Moore, J. C., A. P. Reid and J. Kipfstuhl. 1994. Microstructure and electrical properties of marine ice and its relationship to meteoric ice and sea ice. J. Geophys. Res., 99(C3), 5171-5180.

Morgan, V. I. 1972. Oxygen isotope evidence for bottom freezing on the Amery Ice Shelf. Nature, 238(5364), 393-394.

Napoléoni, J.-G. P. and G. K. C. Clarke. 1978. Hot water drilling in a cold glacier. Can. J. Earth Sci., 15(2), 316-321.

Nicholls, K.W. 1997. Predicted reduction in basal melt rates of an Antarctic ice shelf in a warmer climate. Nature, 388(6641), 460-462.

Nicholls, K.W., K. Makinson and A. V. Robinson. 1991. Ocean circulation beneath the Ronne Ice Shelf. Nature, 354(6350), 221-223.

O'Brien, P. E. and P. T. Harris. 1996. Patterns of glacial erosion and deposition in Prydz Bay and the past behaviour of the Lambert Glacier. Pap. Proc. R. Soc. Tasmania, 130(2), 79-85.

Oerter, H. and 6 others. 1992. Evidence for basal marine ice in the Filchner-Ronne Ice Shelf. Nature, 358(6385), 399-401.

Rosenberg, M. and 8 others. 2002. Amery Ice Shelf experiment (AMISOR), marine science cruises AU0106 and AU0207: oceanographic field measurements and analysis. Antarct. CRC Res. Rep. 30.

Rott, H., W. Rack, P. Skvarca and H. De Angelis. 2002. Northern Larsen Ice Shelf, Antarctica: further retreat after collapse. Ann. Glaciol., 34, 277-282.

Smith, N. R., D. Zhaoqian, K. R. Kerry and S. Wright. 1984. Water masses and circulation in the region of Prydz Bay, Antarctica. Deep-Sea Res., 31(9), 1121-1147.

Taylor, P. L. 1984. A hot water drill for temperate ice. CRREL Spec. Rep. 84-34, 105-117.

Tison, J. L., D. Ronveaux and R. D. Lorrain. 1993. Low salinity frazil ice generation at the base of a small Antarctic ice shelf. Antarct. Sci., 5(3), 309-322.

Tison, J.-L., R. D. Lorrain, A. Bouzette, M. Dini, A. Bondesan and M. Stiévenard. 1998. Linking landfast sea ice variability to marine ice accretion at Hells Gate Ice Shelf, Ross Sea. In Jeffries, M. O., ed. Antarctic sea ice: physical processes, interactions and variability. Washington, DC, American Geophysical Union, 375-407. (Antarctic Research Series 74.)

Tison, J.-L., A. Khazendar and E. Roulin. 2001. A two-phase approach to the simulation of the combined isotope/salinity signal of marine ice. J. Geophys. Res., 106(C12), 31,38731,401 .

Vaughan, D. G. 1993. Implications of the break-up of Wordie Ice Shelf, Antarctica for sea level. Antarct. Sci., 5(4), 403-408.

Wong, A. P. S., N. L. Bindoff and A. Forbes. 1998. On bottom water formation and ocean-ice shelf interaction in Prydz Bay, Antarctica. In Jacobs, S. S. and R. F. Weiss, eds. Ocean, ice and atmosphere: interactions at the Antarctic continental margin. Washington, DC, American Geophysical Union, 173-187. (Antarctic Research Series 75.)

Young, N.W. and G. Hyland. 2002. Velocity and strain rates derived from InSAR analysis over the Amery Ice Shelf, East Antarctica. Ann. Glaciol., 34, 228-234. 